\title{
TESTICULAR MATURATION OF Oligosarcus hepsetus (CUVIER) (ACTINOPTERYGII, CHARACIDAE) IN A BRAZILIAN TROPICAL RESERVOIR
}

\author{
SANTOS, R. N., ANDRADE, C. C., SANTOS, L. N., \\ SANTOS, A. F. G. N. and ARAÚJO, F. G. \\ Laboratorio de Ecologia de Peixes, Universidade Federal Rural do Rio de Janeiro, \\ Antiga Rodovia Rio-SP, Km 47, CEP 23851-970, Seropédica, RJ, Brazil \\ Correspondence to: Francisco Gerson Araújo, Laboratorio de Ecologia de Peixes, \\ Universidade Federal Rural do Rio de Janeiro, Antiga Rodovia Rio-SP, Km 47, \\ CEP 23851-970, Seropédica, RJ, Brazil, e-mail: gerson@ufrrj.br
}

(With 3 figures)

Received May 6, 2003 - Accepted October 13, 2004 - Distributed February 28, 2005

\begin{abstract}
Six reproductive classes of male Oligosarcus hepsetus (Cuvier, 1829), a medium-sized carnivorous Characiform species, are described based on macroscopic and histological techniques. A total of 175 individuals were caught monthly between April 2001 and June 2002 in the Lajes Reservoir, Brazil, one of the largest impoundment areas in the state of Rio de Janeiro. The reproductive classes were based upon changes in the testicular morphology and stages of germinative cells, i.e., resting, early maturing, late maturing, mature, partially spent and totally spent. Fish in the resting class showed testes with spermatogonia and spermatocytes along the wall of seminal lobules, while spermatids were present in the lumina of the lobules. During early maturing, active spermatogenesis occurs throughout the testis; in the late maturing and mature classes, the lobules are swollen with sperm that are typical of fish in breeding condition. Spent testes presented seminal lobules with residual spermatozoa, coinciding with decreasing GSI and greatly reduced sperm production. Overall, the testicular morphology and class of maturity development of $O$. hepsetus in the Lajes reservoir did not differ significantly from those of closely related species in other lentic environments. Lower GSI values in the oligotrophic Lajes reservoir than in other eutrophic natural lakes suggest that this species may be modifying this aspect of its reproductive strategy in response to the artificial environment.
\end{abstract}

Keywords: Characiforms, reproduction, reservoirs, spermatogenesis, testis.

\section{RESUMO}

\section{Maturação testicular de Oligosarcus hepsetus (Cuvier) (Actinopterygii, Characidae) em um reservatório tropical brasileiro}

Seis classes de maturação dos testículos de Oligosarcus hepsetus (Cuvier, 1829), um Characiforme carnívoro de médio porte, foram descritas com base em técnicas macro e microscópicas. Um total de 175 indivíduos foi capturado mensalmente entre abril/2001 e junho/2002 no Reservatório de Lajes, Brasil, uma das maiores áreas represadas do Estado do Rio de Janeiro. As classes reprodutivas foram estabelecidas de acordo com mudanças na morfologia dos testículos e nos estádios das células germinativas: repouso, maturação inicial, maturação final, maduro, parcialmente esvaziado e totalmente esvaziado. Os testículos da classe em repouso apresentaram espermatogônias e espermatócitos ao longo da parede dos túbulos seminíferos, enquanto as espermátides foram encontradas no lúmen dos túbulos. Nos testículos em maturação inicial, a espermatogênese é intensa; em maturação avançada e maduros, os túbulos estão repletos de sêmen, que são característicos de peixes aptos a reprodução. Testículos esvaziados apresentaram sêmen residual nos túbulos seminíferos, coincidindo com a diminuição do IGS e com uma grande redução na 
espermatogênese. Em geral, a morfologia dos testículos e o desenvolvimento das classes de maturação de $O$. hepsetus no Reservatório de Lajes não diferiram de espécies similares em outros ambientes lênticos. Os menores valores do IGS para o reservatório oligotrófico de Lajes, quando comparados com lagos naturais eutróficos, sugerem que $O$. hepsetus pode estar alterando este aspecto de sua estratégia reprodutiva no ambiente artificial.

Palavras-chave: Characiformes, espermatogênese, reprodução, reservatórios, testículos.

\section{INTRODUCTION}

Oligosarcus hepsetus (Cuvier, 1829) is a very common Characidae species in many rivers and lakes of southeastern Brazil. It is a small to medium-sized carnivorous fish usually inhabiting shallow microhabitats with dense vegetation, and is abundant in tributaries or littoral zones of major rivers (Gery, 1977). O. hepsetus ranks among the most abundant fish species in the Lajes reservoir, one of the largest impoundment areas in the state of Rio de Janeiro, which suggests its successful adaptation to the artificial lentic conditions.

A total of 28 fish species, 22 natives and 6 non-indigenous, inhabit this artificial environment (Araújo \& Santos, 2001). Over time, these species must have developed a strategy to adapt and coexist in the new water system, which is almost a century old. The reproductive strategy plays an important role in the adaptive success of a species, for it reflects the potential of a population to produce viable descendents (Vazzoler, 1996). To increase their reproductive success males should be able to fertilize as many eggs as possible. The results depend on the number and fecundity of the females and also on the fertilization capacity of the males; i.e., the number and viability of the sperm cells (Rajasilta, 1997).

Little information exists on the reproductive biology of the genus Oligosarcus, especially concerning the males' testicular morphology and maturity class. Hartz et al. (1997) and Fialho et al. (1998) studied some aspects of the reproduction of this genus, but they made no histological analysis to propose maturity classes for gonadal development. Thus, the majority of researches on fish reproduction have focused on the female, in which gamete production is more costly than in the male (Tomasini \& Laugier, 2002). Little attention has focused on the reproductive cycle and testicular changes of males. Although changes in testicular volume, histology, gonadosomatic indexes and other reproductive scores have all been used to document the reproductive cycle, the underlying mechanisms of testicular growth and regression are poorly understood. The aim of the present study was to describe the testicular morphology, investigating macro and microscopic structures as well as cell distribution of the spermatogenic lineage, to establish testis maturity classes of Oligosarcus hepsetus and to shed some light on this species' reproduction in terms of male gonadal development.

\section{MATERIAL AND METHODS}

The Lajes reservoir $\left(22^{\circ} 42^{\prime}-22^{\circ} 50^{\prime} \mathrm{S} ; 43^{\circ}\right.$ $53^{\prime}-44^{\circ} 05^{\prime} \mathrm{W}$ ) is a major impoundment in the state of Rio de Janeiro, situated on the upper slopes of the Serra do Mar on Brazil's southeastern coast. The reservoir, located at about $415 \mathrm{~m}$ above mean sea level, covers an area of approximately $30 \mathrm{Km}^{2}$ and is a well preserved oligotrophic environment.

The fish were collected between April 2001 and June 2002 using gill nets $(20 \times 2 \mathrm{~m}$, with a 2.5-5.5 mm mesh size). The nets were set up in the late afternoon and retrieved the following morning, remaining in the water for about $12 \mathrm{~h}$. All the fish were preserved on ice at $4{ }^{\circ} \mathrm{C}$ in isothermal containers in the field and later transferred to the laboratory for gonadal dissection and measurements.

A total of 175 males were captured, ranging from 85 to $211 \mathrm{~mm}$ (total length - TL) and weighing 14.11 to $185.28 \mathrm{~g}$ (total weight $-\mathrm{TW}$ ). Testes were fixed in buffered formalin $10 \%$ and dehydrated in sequential alcohol solutions. The preserved testes were embedded in paraffin, sectioned into 5-7 $\mu \mathrm{m}$ thick slices, and stained with Harris Hemaetoxylin and Eosin (H\&E). A minimum of two slides were prepared from each testis.

The gonads were classified according to six reproductive classes: resting, early maturing, late maturing, mature, partially spent and totally spent. The gonadosomatic index (GSI) was determined 
according to the equation: $\mathrm{GSI}=\mathrm{GW} /(\mathrm{TW}-\mathrm{GW})$, where: $\mathrm{GW}=$ gonad weight, $\mathrm{TW}=$ total body weight. Comparisons of mean GSI values were made among the development stages using oneway analysis of variance (ANOVA).

\section{RESULTS}

\section{Testicular morphology}

Macroscopic examinations revealed that Oligosarcus hepsetus has a pair of longitudinally flat testes located in the posterior portion of the abdominal cavity and suspended by the mesorchium. The testes are filiform and joined in the caudal region, forming a common duct that leads to a genital pore.

Males were observed in every maturity class of the reproductive cycle except the immature class. The testes showed transversal folds in the median area, with the anterior border streamlined or slightly curved in the early maturation stages and truncated in the other classes of the reproductive cycle.

The testis is covered by an albuginea tunic of conjunctive origin, hundreds of smooth muscle cells and blood vessels, which sends out septa to the inner part of the organ, forming lobes that are filled with seminal lobules. The seminal lobules are composed of cysts, which are defined by cytoplasmatic projections of Sertoli cells. The spermatogenetic cells in each cyst are in a stage of development similar to that of the testis lineage cells, changing according to the maturity class.

\section{Spermatogenesis}

\section{Spermatogonia (Fig. 1)}

There are two types of spermatogonia: primary and secondary. Primary spermatogonia, the largest cells of the spermatogenic lineage, have a clear cytoplasm and a large prominent nucleus. Primary spermatogonia occur isolatedly and show no cysts. Secondary spermatogonia are composed of the primary ones but are smaller and form cysts comprising a few cells.

\section{Spermatocytes (Fig. 1)}

These cells are divided into primary and secondary spermatocytes. Primary spermatocytes are formed after repeated mitotic divisions of secondary spermatogonia, and are found in several phases of the meiotic prophase, commonly zygotes and pachytenes. The nucleus is prominent with filamentous chromatin. Secondary spermatocytes are smaller than primary ones and their nucleus has slightly condensed chromatin in one of the poles.

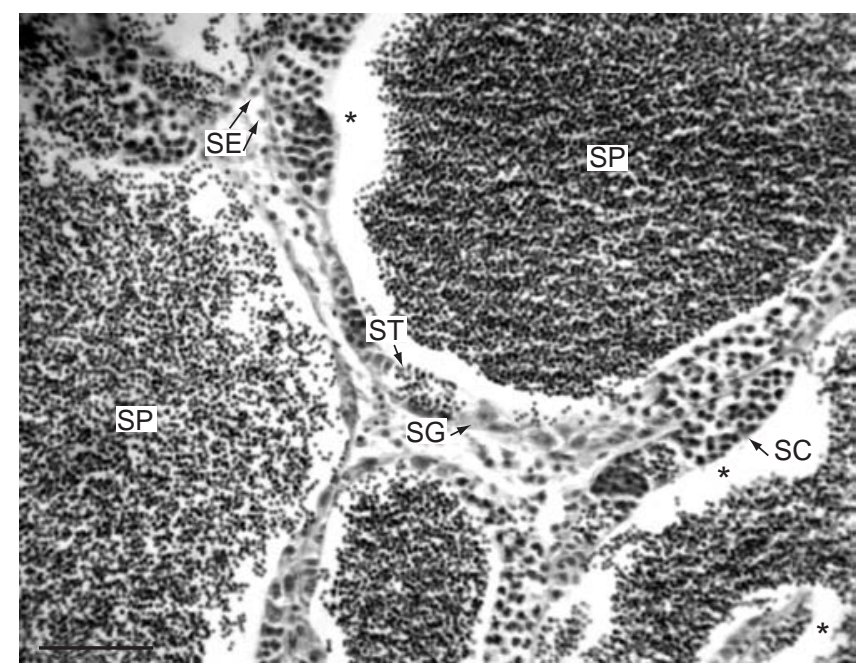

Fig. 1 - Histological section of Oligosarcus hepsetus testis. Spermatogonia (SG), Spermatocytes (SC), Spermatid (ST), Spermatozoa (SP), Sertoli Cells (SE), continuous space between sperm and the lobular germinal epithelium (*). Scale bar $=30 \mu \mathrm{m}$. 


\section{Spermatids (Fig. 1)}

Spermatids originate from the secondary spermatocytes but are smaller than the latter. Cytoplasm is sparse. The nucleus is spherical and dense. These cells undergo modifications until they become spermatozoa.

\section{Spermatozoa (Fig. 1)}

Spermatozoa, the smallest cells of the spermatogenic lineage, have spherical and very dense nucleii. They concentrate in the seminal lobules after breaking through the cyst wall.

\section{Testes maturity classes}

\section{Resting (Fig. 2a)}

The testes are small, filiform and translucent. Though thin, they occupy up to $10 \%$ of the coelomic cavity. Germinal cysts containing spermatogonia and spermatocytes were observed along the wall of seminal lobules, while spermatids occurred in the lumina of seminal lobules.

\section{Early maturing (Fig. 2b)}

The testis in this class is larger than in the resting class, with a filiform appearance, a whitish color, and occupying $15 \%$ of the coelomic cavity. The number of spermatocytes and spermatids in this class was found to be higher, and the spermatids were mixed with germ cells of other stages in the lumina of seminal lobules.

\section{Late maturing (Fig. 2c)}

The testis in this class is ribbon-shaped, yellowish brown, turgid and voluminous, and occupies up to $25 \%$ of the coelomic cavity. Active spermatogenesis occurs in the testis at this stage. Spermatids and spermatozoa are more abundant in the lumina of the seminal lobules than in the early maturing class.

\section{Mature (Fig. 2d)}

The testis showed the largest volume (up to $35 \%$ of the coelomic cavity), with intense vascularization and a yellowish brown color. A large amount of spermatozoa and a few spermatids were recorded in the lumina of seminal lobules and sperm duct. Spermatogonial divisions and further spermatogenesis were found to occur in the seminal lobules, although germinal cysts containing spermatogonia and spermatocytes were absent from the walls of seminal lobules.

\section{Partially spent (Fig. 2e)}

White to reddish testis with flaccid portions, occupies an average of $30 \%$ of the coelomic cavity. Scattered and fewer spermatocysts resulting in reduced sperm production.

\section{Totally spent (Fig. 2f)}

Reddish, strongly hemorrhagic and flaccid testis occupying up to $15 \%$ of the coelomic cavity. Only residual spermatozoa are found in the lumina of seminal lobules that remain partially open.

\section{Gonadosomatic index (GSI)}

The mean GSI values $(\mathrm{F}=12.0 ; \mathrm{P}<0.01)$ revealed significant differences among the maturity classes, with the highest and the lowest values corresponding to the mature and totally spent classes, respectively (Fig. 3). The GSI values were higher in the late maturing and partially spent classes than in the resting and early maturing classes, but lower than in the mature class. The resting and early maturing classes showed slightly higher GSI values than the totally spent class.

\section{DISCUSSION}

Oligosarcus hepsetus testes are classified as the unrestricted spermatogonial type according to Grier's description (1981), because spermatogonia occur throughout the seminal lobules. The spermatogenesis described for $O$. hepsetus showed germinal cysts within each seminal lobule extending from the ducts to the periphery of the testis, with germinal cysts in lobules displaying synchronous differentiation. Grier (1981) named this type cystic spermatogenesis. This pattern differs from some teleosteans (e.g., blenniid), in which various germ cells developing from spermatocytes into spermatids are released from the germinal cysts into lobules or tubules of the lumina, and these released germs cells are not synchronously differentiated, characterizing the semi-cystic type (Lahnsteiner \& Patzner, 1990a; 1990b). Overall, O. hepsetus testes are very similar to other oviparous species of the Characidae family, such as the Brycon cephalus described by Romagosa et al. (1999) and Bryconops affinis reported by Andrade et al. (2001), which show secretory activity during spermatogenesis. 

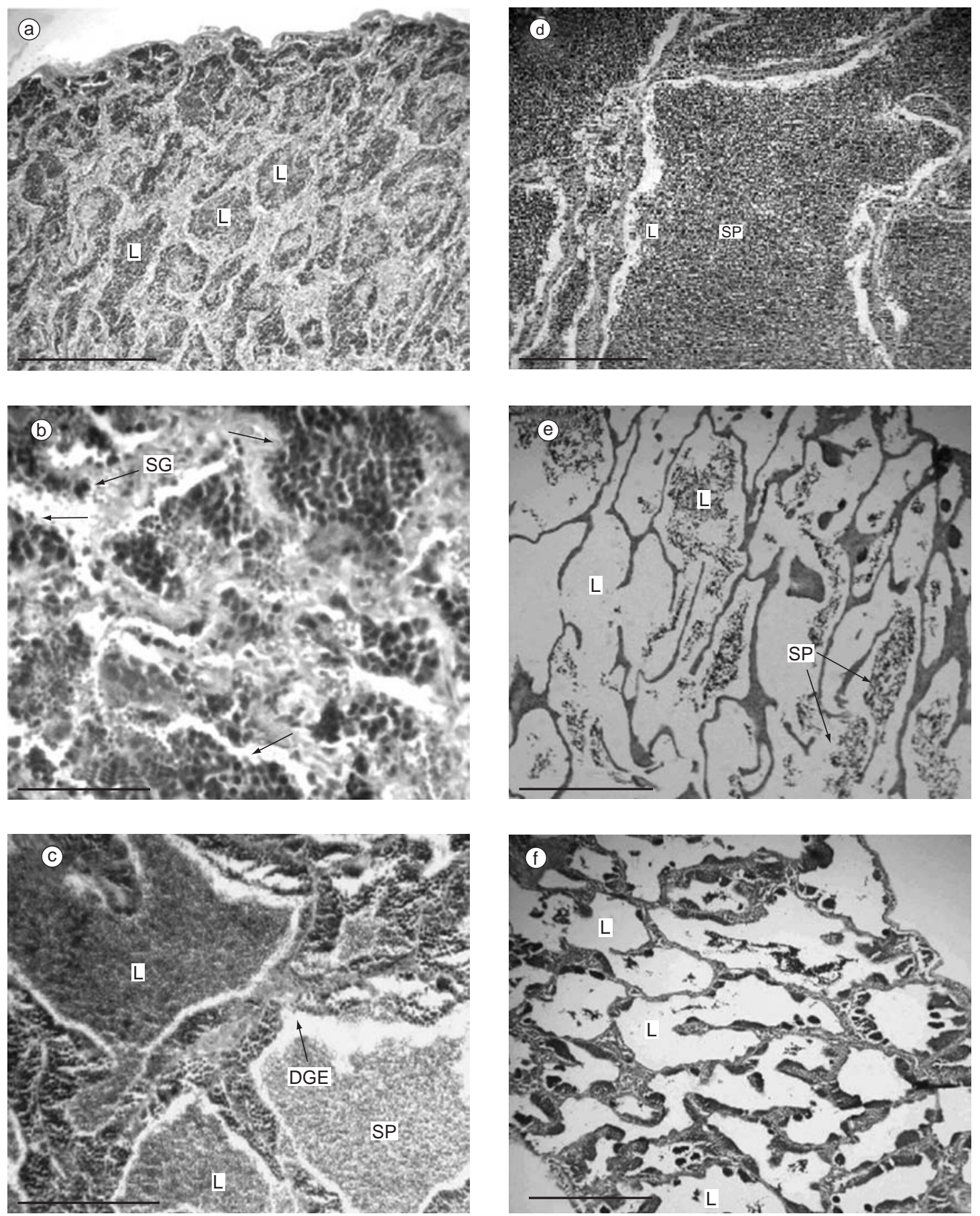

Fig. 2 - Histological sections of Oligosarcus hepsetus testis in different maturity classes. Note the elongation of seminal lobules during the testicular development. a) Testis resting class, tunica (t), lumina of seminal lobules (L) scale bar $=100 \mu \mathrm{m}$; b) early maturing, Spermatogonia (SG), Spermatocytes (arrows); scale bar $=50 \mu \mathrm{m}$; c) Late maturing, discontinuous germinal epithelium (DGE), continuous space between sperm and the lobular germinal epithelium; scale bar $=200 \mu \mathrm{m}$; d) Mature class, scale bar $=200 \mu \mathrm{m}$; e) Partially spent, scale bar $=200 \mu \mathrm{m}$; and f) Totally spent testis, seminal lobules (L) scale bar $=200 \mu \mathrm{m}$. 


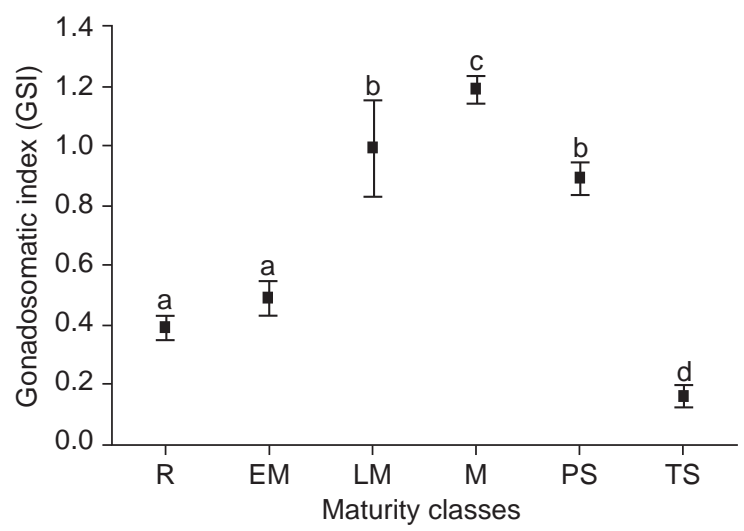

Fig. 3 - Means \pm standard error for Gonadosomatic Index (GSI) per maturity class. $\mathrm{R}=$ resting; EM = early maturing; $\mathrm{LM}=$ late maturing; $\mathrm{M}=$ mature; $\mathrm{PS}=$ partially spent; and $\mathrm{TS}$ = totally spent.

This suggests similar reproductive tactics which probably enable these fish to adapt to and/or occupy the most diverse habitats (Winemiller, 1989).

The maturity classes comprise the continuum of morphological changes in the testis during a reproductive cycle. Early maturing is characterized when spermatogenesis is initiated in the continuous germinal epithelium; late maturing begins when a discontinuous germinal epithelium or at least one lobule within a histological section occurs. According to Grier \& Taylor (1998), during maturation lobules grow by an elongation process but random bifurcations develop, probably because of the orientation of dividing primary spermatogonia when they commence the mitosis. In $O$. hepsetus the elongation of testicular lobules during maturation produces a branching system forming a multiple pathways for sperm egress. In the mature class testis, large quantities of spermatozoa and a few spermatids are present in the lumina of seminal lobules and sperm duct. This class is comprised of fish in breeding condition (Tomasini \& Laugier, 2002). The spent class is characterized by a decrease in the GSI and greatly reduced sperm production.

The number of gonadal classes can vary according to the testicular development of each species and also according to each author's particular criteria. Maturity classes, defined by macroscopic techniques, have been used to describe gross morphological patterns in testes. Furthermore, histological techniques to describe maturity classes supply additional information, decreasing the probability of misleading interpretation of findings. The six classes of testis development described here for $O$. hepsetus (resting, early maturing, late maturing, mature, partially spent and totally spent) are similar to those proposed by Bazzoli \& Godinho (1991) for the closely related Acestrorhynchidae Acestrorhynchus lacustris in the Três Marias reservoir, using histological techniques. However, the latter study found no resting class and the mature class was combined with late maturing. No immature individuals were found In the present study. The smallest fish caught had an $85 \mathrm{~mm}$ TL. With that size, most fish are likely to have reached their first maturing stage. Bazzoli \& Godinho (1991) found similar results for A. lacustris. Using solely macroscopic techniques, Hartz et al. (1997) recorded four testis maturity classes for the gonadal development of Oligosarcus jenynsii in the Caconde Lagoon in Rio Grande do Sul, but found no immature or resting stages. Fialho et al. (1998) described five maturity classes for $O$. jenynsii in the Custódia Lagoon, Rio Grande do Sul, but no resting stage.

The GSI has been widely used as an indicator of the fish spawning period, but its use in reproductive biology studies is more suitable when associated with other reproduction indicators such as macroscopic and histological techniques. This is important for males, since differences in size and weight are less conspicuous than in females (Chaves, 1991). In O. hepsetus, the GSI increases from the resting to the maturing class, reaching a peak in mature testes, followed by a decreasing 
trend to the spent class, which is the expected pattern for teleostean fishes (Teles \& Godinho, 1997). A similar GSI pattern was found by Fialho et al. (1998) for O. jeninsii from the Custódia Lagoon, while Bazzoli (1985) recorded a different pattern for A. lacustris from the Três Marias Reservoir, with a high GSI in early maturing testes and a decreasing trend towards the spent class. The GSI values of $O$. hepsetus also differed from those found by Fialho et al. (1998) for $O$. jeninsii and by Bazolli (1985) for A. lacustris, when comparing each maturity class. Overall, the GSI values for $O$. hepsetus were lower than those of $O$. jeninsii from the Custódia Lagoon (Fialho et al., 1998) but higher than those of A. lacustris from the Três Marias Reservoir (Bazzoli, 1985), mainly for the mature classes. These differences seem to be related with the environmental characteristics of each ecosystem, since the lower GSI values found for $O$. hepsetus and A. lacustris may be explained by impoundment impacts resulting in limited food supply and, hence, negative effects on reproductive strength. Both the Lajes and Três Marias reservoirs are oligothrophic with highly transparent water, showing strong water level fluctuations dictated by the hydroelectric demand; these factors could be influencing the GSI values. Otherwise, the highest GSI values recorded for $O$. jeninsii suggested the strong adaptation of this species to favorable conditions in this natural lagoon-estuarine system (Fialho et al., 1998), where food and habitat availability are usually high and environmental conditions are more stable.

Overall, the testis morphology and maturity development class of $O$. hepsetus in the Lajes reservoir did not differ significantly from those of closely related species in other lentic environments. On the other hand, the higher GSI values of native (stable and productive) systems than of artificial oligotrophic ecosystems suggest that this species may be modifying some aspects of its reproductive strategy in the artificial environment.

Acknowledgments - This study was partially financed by CNPq (Brazil's National Council for Technological and Scientific Development) and CAPES (Brazil's Ministry of Education Coordinating Office for the Betterment of University Graduates). LIGHT S.A. - Electricity Services, leaser of the Lajes reservoir, supplied the infrastructure essential for development of this project as well as additional financial support. We are especially grateful for the help extended to us by Drs. Sebastião Paulino and Ricardo Bichara. Our heartfelt thanks also go to the many technicians and undergraduate students of the Federal Rural University of Rio de Janeiro's Fish Ecology Laboratory for their assistance in the field and laboratory work, as well as to the Histological Techniques Laboratory staff, particularly to Aparecida Alves Nascimento, MSc.

\section{REFERENCES}

ANDRADE, R. F., BAZZOLI, N., RIZZO, E. \& SATO, Y., 2001, Continuous gametogenesis in the neotropical freshwater teleost, Bryconops affinis (Pisces: Characidae). Tissue \& Cell, 33(5): 524-532.

ARAÚJO, F. G. \& SANTOS, L. N., 2001, Distribution of Fish Assemblages in Lages Reservior, Rio de Janeiro, Brazil. Rev. Bras. Biol., 61(4): 563-576.

BAZZOLI, N., 1985, Biologia Reprodutiva do peixe-cachorro Acestrorhyncus lacustris (Reinhardt, 1874) (Pisces: Characidae) da Represa de Três Marias, MG, Brazil. Dissertação de Mestrado, UFMG, Minas Gerais, 149p.

BAZZOLI, N. \& GODINHO H. P., 1991, Reproductive biology of Acestrorhyncus lacustris (Reinhardt, 1874) (Pisces: Characidae) from Três Marias reservoir, Brazil. Zoo. Anz., 5-6: 285-297.

CHAVES, P. T. C., 1991, Testículos: estrutura e dinâmica de maturação, pp. 47-50. In: Histologia de peixes. Ed. FUNEP, Jaboticabal, 77p.

FIALHO, B. C., SCHIFINO, L. C. \& VERANI, J. R., 1998, Biologia reprodutiva de Oligosarcus jenynsii (Gunther) (Characiformes, Characidae) da Lagoa das Custódias, Tramandaí, Rio Grande do Sul, Brasil. Rev. Bras. Zool., 15 (3): 775-782.

GÉRY, J., 1977, Characoids of the world. T. F. H. Publications, Neptune City, 672p.

GRIER, H. J., 1981, Cellular organization of the testis and spermatogenesis in fishes. Amer. Zool., 21: 345-357.

GRIER, H. J. \& TAYLOR, R. G., 1998, Testicular maturation and regression in the common snook. J. Fish. Biol., 53: 521-542.

HARTZ, S. M., VILELLA, F. S. \& BARBIERI, G., 1997, Reproduction dynamics of Oligosarcus jenynsii (Characiformes, Characidae) in Lake Caconde, Rio Grande do Sul, Brazil. Rev. Brasil. Biol., 57(2): 295-203.

LAHNSTEINER, F. \& PATZNER, R. A., 1990a, Spermiogenesis and structure of mature spermatozoa in blenniid fishes (Pisces, Bllenniidae). J. Subm. Cytol. Path., 22: 565-576.

LAHNSTEINER, F. \& PATZNER, R. A., 1990b, The spermatic duct of blenniid fishes (Pisces, Bllenniidae): fine structure, histochemistry and function. Zoomorphology, 110: 63-73.

RAJASILTA, M., PARANKO, J. \& LAINE, P. T., 1997, Reproductive characteristics of the male herring in the northern Baltic Sea. J. Fish. Biol., 51: 978-988.

ROMAGOSA, E., NARAHARA, M. Y., BORELLA, M. I., PARIERA, S. F. \& FENERICH-VERANI, N., 1999, Ultrastructure of the germ cells in the testis of matrinxã, Brycon cephalus (Teleostei, Characidae). Tissue \& Cell, 31(6): 540-544.

TELES, M. E. O. \& GODINHO, H. P., 1997, Ciclo reprodutivo da Pirambeba Serrasalmus brandtii (Teleostei, Characidae) 
na represa de Três Marias, rio São Francisco. Rev. Bras. Biol., 57(2): 177-184.

TOMASINI, J. A. \& LAUGIER, T., 2002, Male reproductive strategy and reserve alocation in sand smelt from brackish lagoons of southern France. J. Fish. Biol., 60: 521-531.
VAZZOLER, A. E. A. M., 1996, Biologia da reprodução de peixes teleósteos: teoria e prática. EDUEM, Maringá, $169 \mathrm{p}$.

WINEMILLER, K. O., 1989, Patterns of variation in life history among South American fishes in seasonal environmentals. Oecologia, 81: 225-241. 